\title{
Nitrimidazine (Naxogin) compared with metronidazole (Flagyl) in the treatment of trichomonal vaginitis
}

\author{
A. N. McCLEAN \\ St. Thomas's Hospital, London
}

For more than 10 years very satisfactory results have been obtained in the treatment of trichomonal vaginitis using the standard 7-day course of metronidazole $200 \mathrm{mg}$. three times a day (Rodin, King, Nicol, and Barrow, 1960). In a recent trial it was shown that a 5-day course of $400 \mathrm{mg}$. twice daily produced equally satisfactory results, and was probably an easier regime from the patient's point of view (McClean, 1971).

Nitrimidazine (Naxogin) is a related compound introduced in Italy for treatment of the same condition, and equally satisfactory or better results are claimed for it when used at a dosage of $250 \mathrm{mg}$. twice daily for 6 days (Emanueli and de Carneri, 1969; Signorelli and Emanueli, 1969).

In the trial to be described the two compounds were compared in the treatment of trichomoniasis in women, the 5-day regime being used in the case of metronidazole, and the standard 6-day regime for nitrimidazine.

\section{Material and methods}

The trial, which was carried out in the Lydia Clinic at St. Thomas's Hospital, involved 100 patients presenting with new infections with $T$. vaginalis. Their marital status is shown in Table I.

TABLE I Marital status, excluding pregnant patients

\begin{tabular}{llllll}
\hline Single & Married & $\begin{array}{l}\text { Married } \\
\text { (separated) }\end{array}$ & $\begin{array}{l}\text { Married } \\
\text { (divorced) }\end{array}$ & $\begin{array}{l}\text { Married } \\
\text { (widowed) }\end{array}$ \\
\cline { 1 - 1 } & $\frac{24}{8}$ & $\frac{3}{3}$ & $\frac{3}{3}$
\end{tabular}

Diagnosis was based on findings in wet vaginal smears or results of culture in Feinberg-Whittington medium. Five follow-up examinations over 3 months were aimed for, including at least one examination by culture. Concurrent infections were diagnosed, treated, and followed up, for the same length of time in the usual manner.

AGE

Of the 100 patients, 84 were aged 18 to 35 years, six were younger (all post-pubescent), and ten were older.

Received for publication April 15, 1971

\section{TREATMENT}

Patients were allocated to treatment on a random basis prepared previously and unknown to either patient or prescriber.

Fifty women received $400 \mathrm{mg}$. metronidazole twice daily for 5 days and fifty received nitrimidazine $250 \mathrm{mg}$. twice daily for 6 days. Records were made of further sexual intercourse during the trial period and of symptoms suggesting side-effects.

\section{Results}

Of the fifty patients treated with metronidazole, five (10 per cent.) failed to return, and of the fifty treated with nitrimidazine, eleven ( 22 per cent.) defaulted, and one took only four tablets. These patients were excluded from the trial, leaving a total of 45 in the first group and 38 in the second. The duration of follow-up is shown in Table II.

TABLE II Length of follow-up in patients apparently cured

\begin{tabular}{|c|c|c|c|c|c|}
\hline $\begin{array}{l}\text { Duration of followv-up } \\
\text { (months) }\end{array}$ & $<1$ & $1-2$ & 3 & $\begin{array}{l}\text { More than } \\
3\end{array}$ & Total \\
\hline Metronidazole & 13 & 6 & 5 & 13 & 37 \\
\hline Nitrimidazine & 8 & 7 & 9 & 7 & 31 \\
\hline
\end{tabular}

In these remaining cases in which at least one follow-up test was performed, there were eight failures (18 per cent.) in the first group and seven (18.4 per cent.) in the second (Table III). Four patients complained of side-effects with Flagyl (one depression, one headaches, and two nausea). Two patients complained of side-effects with Naxogin (one depression and nausea and one vertigo). In none of these was it necessary to stop administration of either drug.

The cases of treatment failure (or re-infection) are analysed in Table IV, which shows the interval between treatment and the reappearance of $T$. vaginalis and whether the patient admitted further sexual intercourse. In both groups, several cases of recurrence attributed to treatment failure may well have been due to re-infection. 
TABLE III Analysis of results

\begin{tabular}{|c|c|c|c|c|c|c|c|}
\hline \multirow[t]{2}{*}{ Drug } & \multirow[t]{2}{*}{ Time of assessment } & \multicolumn{2}{|c|}{ Failures } & \multicolumn{2}{|c|}{ Successes } & \multicolumn{2}{|c|}{ Total } \\
\hline & & No. & Per cent. & No. & Per cent. & No. & Per cent. \\
\hline & Immediate & 3 & 7 & & & & \\
\hline \multirow[t]{3}{*}{ Metronidazole } & Later & 5 & 11 & 37 & 82 & 45 & 100 \\
\hline & Total & 8 & 18 & & & & \\
\hline & Immediate & 4 & 10 & & & & \\
\hline \multirow[t]{2}{*}{ Nitrimidazine } & Later & 3 & 8 & 31 & 82 & 38 & 100 \\
\hline & Total & 7 & 18 & & & & \\
\hline
\end{tabular}

TABLE IV Apparent failures, showing follow-up and sexual intercourse

\begin{tabular}{|c|c|c|c|c|c|}
\hline \multirow[t]{2}{*}{ Drug } & & \multicolumn{4}{|c|}{ Duration of follow-up (mths) } \\
\hline & & Less than 1 & $1-2$ & 3 & More than 3 \\
\hline \multirow[t]{2}{*}{ Metronidazole } & Total & 3 & 0 & 1 & 4 \\
\hline & Sexual intercourse & $\begin{array}{l}1 \text { admitted } \\
1 \text { denied } \\
1 \text { unknown }\end{array}$ & $\begin{array}{l}0 \\
0\end{array}$ & 1 admitted & $\begin{array}{l}3 \text { admitted } \\
1 \text { denied }\end{array}$ \\
\hline \multirow[t]{2}{*}{ Nitrimidazine } & Total & 4 & 1 & 1 & 1 \\
\hline & Sexual intercourse & $\begin{array}{l}2 \text { admitted } \\
2 \text { denied }\end{array}$ & 1 denied & 1 admitted & 1 admitted \\
\hline
\end{tabular}

All cases of recurrence, whatever the cause, were given further treatment with metronidazole. Two patients in each group defaulted immediately after re-treatment and the result was therefore not known. Re-treatment was successful in the remaining cases, though in two from the nitrimidazine group, recovery was delayed until there was cessation of sexual intercourse.

\section{Summary and conclusions}

Metronidazole $400 \mathrm{mg}$. twice daily for 5 days and nitrimidazine $250 \mathrm{mg}$. twice daily for 6 days were compared in the treatment of vaginal trichomoniasis in a control trial based on random selection.

Out of 45 patients followed, 37 (82 per cent.) were cured by the former regime, and out of 38 patients followed, 31 ( 82 per cent.) were cured by the latter regime. A significant proportion of the apparent cases of failure with either drug was probably due to re-infection. Toxic effects were minimal with each drug and in no case required suspension of the treatment. The cost of each course was about the same.

Nitrimidazine (Naxogin) thus appears to be equally as effective as the well-established metronidazole (Flagyl).

The author gratefully acknowledges the help and advice of Dr. C. S. Nicol, Senior Consultant in Venereology at St. Thomas's Hospital, in the preparation of this paper. Note: A $400 \mathrm{mg}$. tablet of metronidazole is now available from May and Baker.

\section{References}

EMANUEli, A., and DE CaRneri, I. (1969) 6th Int. Congress of Chemotherapy, Tokyo, A 16-2

McClean, A. N. (1971) Brit. F. vener. Dis., 47, 36.

Rodin, P., King, A. J., Nicol, C. S., and Barrow, J. (1960) Ibid., 36, 147

SignORELII, I., and EmANUELI, A. (1969) Minerva ginec., 21, 23, 1649-1654

La nitrimidazine (Naxogin) comparée au métronidazole (Flagyl) dans le traitement de la vaginite à Trichomonas

\section{SOMMAIRE}

Au cours d'un essai contrôlé de traitement de la vaginite à Trichomonas, fondé sur une sélection randomisée, on a comparé le métronidazole, $400 \mathrm{mg}$. deux fois par jour pendant 5 jours, et la nitrimidazine, $250 \mathrm{mg}$. trois par jour pendant 6 jours.

Sur les 45 malades suivies, 37 ( 82 pour cent) ont été guéries par le premier traitement et, sur les 38 suivies avec le second traitement, 31 ( 82 pour cent) ont été guéries. Une proportion significative de cas apparents d'échec pour les deux médicaments a été probablement due à des réinfections. Les effets toxiques ont été minimes avec chaque produit et n'ont, dans aucun cas, obligé à suspendre le traitement. Le coût de chaque traitement est à peu près le même.

La nitrimidazine (Naxogin) apparaît donc être aussi active que le traitement bien classique par le métronidazole (Flagyl). 